\title{
Akademik Personelin Yıldırma Algılamalarının Değerlendirilmesi: Kırgızistan Türkiye Manas Üniversitesi Örneğ $i^{*}$
}

\author{
Evaluation of academics staff perception on mobbing: the case of Kyrgyz \\ Turkish Manas University
}

\section{Celaleddin SERINKAN ${ }^{1}$}

${ }^{1}$ Pamukkale Üniversitesi, İktisadi ve İdari Bilimler Fakültesi, Denizli. cserinkan@pau.edu.tr

\begin{abstract}
Özet
Araştırmanın amacı, Kırgızistan Türkiye Manas Üniversitesinde (KTMU) çalışan akademik personelin yıldırma hakkındaki tutumların belirlemektir. Ayrica akademisyenlerin demografik özellikleri bakımından aralarında farklılıkların olup olmadığını tespit etmektir. Araştırmanın modeli tanımlayıcı modeldir. Araştırmada veriler, Yıldırma Ölçeği kullanılarak anket yöntemiyle elde edilmiştir. Verilerin değerlendirilmesinde frekans, yüzde, ortalama, standart sapma, $t$ testi ve anova analizlerinden yararlanılmıştır. Araştırma sonuçlarına göre; Türk akademisyenlerin daha fazla sosyal ayrıma uğradıkları, bayan akademisyenlerin daha yüksek yıldırma davranışına maruz kaldıkları tespit edilmiştir. Diğer bir sonuca göre araştırma görevlileri ile öğretim görevlileri daha fazla yıldırmaya tabi olduklarm düşünmektedirler. Ayrıca üç yıldan fazla Kırgızistan Türkiye Manas Üniversitesinde çalışmakta olan akademisyenlerde yıldırma görülmektedir.
\end{abstract}

Anahtar kelimeler: Yildırma, Akademisyenler, Kirgizistan Türkiye Manas Üniversitesi, Kırgızistan.

JEL kodlart: I2, I24, M12, M14.

\begin{abstract}
The purpose of this study, the academic staff of the Kyrgyz Turkish Manas University (KTMU) is to determine their attitudes about mobbing. In addition, it is to determine whether there are differences between the demographics characteristics of academicians. The research design is descriptive model. In the study, data were obtained by questionnaire method using mobbing scale. Data were evaluated by frequency, percentage, mean, standard deviation, $t$-test and ANOVA. According to the results; it was found that Turkish academics were exposed to more social separation and female academicians were exposed to higher mobbing behaviour. According to another result, research assistants and lecturers thought that they are experienced more mobbing behaviour. In addition, academicians have been working at Kyroyz Turkish Manas University more than three years, they have been exposed to the highest level of mobbing score.
\end{abstract}

Keywords: Mobbing, Academicians, Kyrgyz Turkish Manas University, Kyrgyzstan.

JEL codes: I2, I24, M12, M14.

\footnotetext{
* Bu çalışma, 2014 yılında Bişkek'te düzenlenen 6. Uluslararası Girişimcilik Kongresinde sunulan bildirinin genişletilmiş şeklidir.
} 


\section{GİRIŞ}

Bireylerin yaşamlarının önemli bir bölümünü geçirdikleri çalışma ortamları; stresten uzak, psikolojik ve fiziksel baskıların olmadığı yerler ise, bu tür yerlerde verimliliğin ve örgüte bağlılığın arttığı söylenebilir.

Yıldırma (mobbing) kavramı, örgüt içerisinde çalışma ortamını ve çalışanlar arasında da çalışma barışını bozabilen, kişileri stresle karşı karşıya bırakabilen bir unsur olarak karşımıza çıkmaktadır (Köse ve Uysal, 2010: 261).

Bir veya birkaç kişinin bir kişiye yönelik olarak sergilediği organize ve süreklilik arz eden nitelikte, fiziksel ve/veya psikolojik zarara yol açan tacizci davranışlara -saldırganlığayıldırma (mobbing) adı verilir (Dökmen, 2008: 170). Yıldırma konusunda çalışma yapan Baykal'ın aktarmasına göre ülkemizde, Kanuni sultan Süleyman döneminde intihar eden Hüsrev Paşanın ilk mobbing mağduru olduğu belirtilmektedir (Şahin, 2013: 2). Çalışma hayatı içinde, insanlararası münasebetlerde kişileri olumsuz olarak etkileyen bazı durumlarla mücadele etmek gerekmektedir. Bu tür durumlara işyerinde taciz, psikolik taciz, zorbalık, yıldırma gibi isimler verilmektedir (Irak, 2019: 56).

Yıldırma konusunda ilk çalışanlardan biri olan Leyman'a göre; çalışma hayatı içinde psikolojik terör veya yıldırma olarak tanımlanan mobbing, bir veya birkaç kişi tarafından sistematik bir şekilde yönlendirilen düşmanca ve etik olmayan davranışlardır. Bu davranışların hemen hemen her gün olduğu ve uzun bir süre boyunca gerçekleştiği (en az altı ay) ve bu durumun kişide psikolojik, psikosomatik ve sosyal çöküntüye yer açmasıdır (Leymann, 1990: 120). Özel sektörde zorbalık (bullyıng) olarak da tanımlanan yıldırmanın pek çok alanda çalışılmasına rağmen akademik hayatta bu konu yeterince üzerinde durulmamıştır (Keashly ve Neuman, 2010: 8; Miller vd., 2019: 48).

Bu araştırmada Kırgızistan'ın en büyük üniversitesitelerinden biri olan Kırgızistan Türkiye Manas Üniversitesinde görev yapan akademik personelin yıldırmaya karşı algılamaları belirlenmeye çalışılmıştır. Araştırma 2014 yılının ilk aylarında gerçekleştirilmiş olup toplam 73 kişi araştırmaya katılmıştır. Araştırmada sadece Türkçe olarak hazırlanan anket formunun kullanılması nedeniyle Türkçe bilen akademisyenlere anket uygulanmıştır.

\section{TEORIKK TEMEL}

Dünyada örgütsel psikoloji alanında çalışanların artan bir ilgiyle araştırdıkları yıldırma (mobbing) kavramı, Türkiye'de son birkaç yıldır araştırılan bir olgudur. İş hayatında yer alan hemen herkesin doğrudan ve/veya dolaylı olarak karşılaştığ duygusal taciz vb. kavramlarla da ifade edilen yıldırma olgusu, işyerlerinde çalışanlara, bir veya birkaç kişi tarafından gerçekleştirilen sistemli, ahlak dışı, düşmanca davranışları ifade etmektedir. Çalışanlar üzerinde nasıl uygulandığı konusunda herhangi bir sınırı bulunmayan yıldırma davranışları, bir örgütsel psiko-şiddet biçimidir. Bastırma, sindirme, bunaltma, korkutma, tehdit etme gibi taktiklerle uygulanan yıldırma, iş tatminsizliğinin, örgütsel çatışma ve verimsizliğin temel kaynağı olarak görülmektedir. Diğer taraftan, konu üzerinde yapılmış olan çalışmalarda genellikle görmezlikten gelinen, müsamaha edilen veya yanlış tanımlanması yoluyla "bir işyeri davranışı" olarak kabul gören yıldırma; bireysel, örgütsel ve toplumsal etkileri nedeniyle günümüzde en ciddi sorunlardan biri olarak ifade edilmektedir (Kök, 2006: 434). 
Çalışanların yıldırma sebebiyle yaşadıkları bu rahatsızlıklar ailesiyle iletişimden uzaklaşarak evliliklerini, çocuk ilişkilerini ve çocukların psikolojik gelişimlerini etkilemektedir. İşletmelerde azalmış verimlilik ve üretkenlik, ürün kalitesinde azalma, işletme imajındaki kayıplar, müşteri sayısında azalma olarak karşımıza çıkar. Yıldırmanın ekonomiye olan etkisini net olarak söylemek mümkün değildir. National Safe Workplace Enstitüsünde uzman raporuna göre Birleşik Devletlerde işyeri şiddetinin çalışanlara toplam maliyeti 1992 yılında 4 milyar dolardan fazladır. British Columbia Workers Compensation Board'a göre Kanada'da işyeri şiddeti ile ilgili kanunun yürürlüğe girmesiyle 1985'den itibaren hastane çalışanları tarafından açılan ücret kaybı davaları \% 88 artış göstermiştir. Almanya' da psikolojik şiddetin 1000 çalışanlı bir girişime direkt maliyeti 112.000 dolar, bunun yanında dolaylı maliyeti ise 56.000 dolar olarak hesaplanmıştır. Bununla birlikte genel olarak yaşanan sağlık problemleri nedeniyle yapılan sağlık harcamalarının artması, sigorta masraflarında artış, işsizlik ve kapasite altı çalıştırılmadan doğan vergi kayıpları, devletin sağladığı yardım programlarına yönelen talebin artması tüm toplumun katlanmak zorunda olduğu ekonomik maliyet olarak belirtilebilir. Mutsuz bireyler ve aileler, çalışma barısının olmadığı bir iş hayatı da yıldırmanın ortaya çıkardığı büyük bir toplumsal problem olarak düşünülebilir (Hacıcaferoğlu, 2010: 5657).

1980'lerde Leymann bu davranışın iş yaşamında olduğunu ifade etmiştir. Bu davranışların işyerinde olduğunda "Mob" kökünden türetilen mobbing olarak ifade edilmektedir. Mobing kavram olarak, işyerinde yıldırma, zorbalık veya duygusal taciz olarak adlandırılmaktadır. Psikolojik yıldırma eylem olarak, bir bireyin ya da bir grubun hedef seçilmiş kişiye karşı uyguladıkları 1srarlı, aşağılayıcı, sistematik, hakir görücü, yıldırıcı, haksız, söz ve davranışlarıdır. Bu boyutuyla psikolojik yıldırma, öfkeli ya da kızgın bir kalabalığın ses çıkararak diğer kişilere karşı birlikte saldırıya geçmesidir. Leymann"a göre işyeri zorbalığı kendini savunamayacak durumda olan bir kişinin, işyerindeki bir kişi ya da grubun sistematik bir biçimde düşmanca ve ahlaki olmayan davranışlarına hedef olması şeklinde tanımlamıştır (Mete, 2013: 979).

"Bullying" kavramı ise Mobbing kavramına yakın bir kavramdır. Genellikle "mobbing" yaşamın her alanında kullanılan caydırma, sindirme, mağdurun benliğini öldürme, izole etme gibi anlamlara gelirken, "bullying” kavramı, daha güçlü bir kişi ya da grup tarafından daha zayıf kişi ya da kişilere karşı uygulanan ve sürekliliği olan psikolojik ya da fiziksel baskı anlamına gelmektedir. Leymann, bullying kelimesini okul çocukları ve gençler arasındaki faaliyetler olarak, mobbing kelimesini de yetişkin davranışı olarak kullanmaktadır. Bullying okulda Mobbing kavramına yakın bir kavram gençler ve çocuklar arasında, mobbing ise işyerinde yetişkinler arasındaki karmaşık davranışlardır (Köse ve Uysal, 2010: 6).

Yıldırma olgusu çalışanlar ve aileleri, işletme hatta ülke ekonomisi üzerinde dahi etkilidir. Yıldırmaya maruz kalan çalışanlar depresyon, panik atak krizleri, korkular, heyecanlar, yüksek tansiyon, dikkati toplayamama, uyum bozukluğu, travma sonrası stres bozukluğu, ellerin terlemesi ve titremesi, yersiz sıcak basma veya üşüme duygusu, titreme, boğazda dügüm ve ya hava açlığı hissetme, baş ağrıları, basta ağırlık hissetme, sırt ağrıları, bağışıklık sisteminde düşüş, mide-bağırsak rahatsızlıkları, terkedilmiştik duygusu, iştahsızlık, zayıflama, deri üzerinde döküntüler ve kasıntılar, vb. yüz üç ağır fiziksel semptomlarla karşılaşılmaktadır. Mobbing'in çok yoğun yaşandığı durumlarda mobbing mağdurunda intihar düşünceleri dahi ortaya çıkabilmektedir (Kocaoğlu, 2007: 48). 
Üniversiteler özgür düşüncenin yer aldığ 1 ve düşünceyi ifade etmenin serbest olduğu yerler olarak belirtilmesine rağmen mobbingle anılması ciddi bir tezat oluşturmaktadır. Bu nedenle bu hassasiyete sahip üniversitelerde çalışan akademisyenlerin mobbing konusundaki genel ve kurumsal algılarının belirlenmesi bu açıdan oldukça önem arz etmektedir. Genel olarak üniversiteler yıldırma hakkında anılmak istememektedir. Ancak insan unsurunun olduğu her örgütte azda olsa mobbingle karşılaşılması kaçınılmazdır. Türkiye'de özel ve kamu üniversitelerinde çalışan akademisyenlerin mobbing algılarını tespit etmeye yönelik gerçekleştirilen birçok araştırma, yıldırmanın varolduğunu teyit etmektedir (Güven vd., 2018: 44). Üniversitelerde akademisyenlerin yıldırma davranışına maruz kalmalarıyla ilgili araştırma sonuçlarına göre; akademisyenlerin yarısından çoğunun yıldırmayla karşılaştıkları, yıldırma uygulayıcılarının çoğunluğunun da yöneticilik görevlerinin olduğu ve profesör ve doçentlerin diğer akademisyenlere yıldırma uyguladıkları tespit edilmiştir (Öztürk, 2019: 322).

Fettahlığlu'nun 2008 belirtiğine göre, Yıldırma konusunda, Yüksek Öğrenim Kurumu (YÖK)' nun tezlere ilişkin veri tabanına göre doktora ve yüksek lisans seviyesinde yapılmış 14 ayrı tez mevcut olduğu belirtilirken çeşitli makale ve bildirilerin olduğunu, fakat akademik personel üzerine yurt içi ve yurt dışı literatürde kapsamlı bir çalışmanın yapılmadığı belirtilmektedir (Fettahlığlu, 2008: 188).

Türkiye'de yıldırma (mobbing) konusunda yapılan akademik araştırmaların sayısında epey artış olmuştur. Yorulmaz'ın yapmış olduğu meta analiz çalışmasında belirtiği gibi YÖK'te kaydı bulunan çalışma adedi 454'tür. Bunların 427'si yüksek lisans tezi, 30'u doktora ve 4'ü ise tıpta uzmanlık tezidir. Tezlerin 23'ü İngilizce olarak hazırlanmış olup bunların tamamı yüksek lisans tezidir. Toplam 96 üniversitede bu konuda tez çalışması yapılmıştır (Yorulmaz, 2019: 1637).

Üniversitelerde akademisyenlerle ilgili yıldırma konusunda araştırmalar yeterince değildir (Altınkurt, 2012: 76; Coşkuner, 2018: 25). Bununla birlikte son yıllarda yükseköğretimde yıldırma konusunda yapılan araştırmalar artış göstermektedir (Minibaş, 2018: 472). Hatta üniversiteler arası karşılaştırmaların yapıldı̆̆ı araştırmalar bulunmaktadır (Pugh ve Krestelica, 2019: 110). Türkiye'de ve dünyada yıldırma konusunda araştırmalar artarken Kırgızistan'da bu konuda yapılan araştırma sayısı oldukça azdır. Bu çalışma ile literatüre katkı sağlanacağı düşünülmektedir.

\section{GEREÇ VE YÖNTEM}

$\mathrm{Bu}$ çalışmada, Kırgızistan Türkiye Manas Üniversitesinde çalışan akademisyenlerin yıldırmaya karşı eğilimlerini belirlemek amaçlanmıştır. Ayrıca katılımcıların demografik özellikleri açısından yıldırma ve yıldırma boyutlarında farklılıkların olup olmadığı araştırılmıştır.

Araştırmanın yapıldığı 2014 tarihinde, Kırgızistan Türkiye Manas Üniversitesinde (KTMU) 373 öğretim elemanı bulunmaktadır (İstatistiklerle Manas, 2018). Araştırmada anket yöntemi uygulanmış olup Türk akademisyenler ve Kırgız akademisyenlerin arasında Türkçe bilenler araştırmaya dâhil edilmiştir. Ayrıca pekçok akademisyen araştırmaya cevap vermek istememiştir. $\mathrm{Bu}$ nedenle amaçlı örnekleme yöntemi tercih edilmiştir. Araştırma tamamlandığında 73 geçerli ankete ulaşılmıştır. Ünvanlara göre sıralama yapıldığında grupların sayılarının dengesiz olması nedeniyle doçent grubuyla profesörler birleştirilmiştir. 
Yaş açısından cevaplayıcılar arasında dengesizlik olduğu için 41-50 yaş grubu ile 50' den fazla yaş grubu birleştirilmiştir. Cevaplayıcı kitlesinin nispeten az olması, araştırma sonuçları hakkında kısmen fikir verse de üniversitenin geneline şamil olamayacağı, araştırmanın kısıtını oluşturmaktadır. Ayrıca KTMU'de Türkiye'deki üniversitelerden geçici görevlendirmeyle gelmiş olan öğretim üyelerinin sözleşmeleri birer yıllık olarak yapıldığı ve en fazla beş yıl kalınabilmektedir. Yurt dışında çalışmanın zorluklarının bariz şekilde görüldüğü Kırgızistan'da çalışma yılları, akademisyenler için büyük önem arzetmektedir. Bu yüzden çalışma sürelerinde birleştirme yapılmamıştır.

Araştırmada veriler, 56 soruluk anket formuyla elde edilmiştir. Anket formunun ilk 51 sorusu yıldırma ölçeğini, son altı sorusu ise demografik özellikleri oluşturmaktadır. Manas'taki akademisyenlerin yıldırma ve boyutlarını yaşayıp yaşamadıklarını ortaya koymak amacıyla, Uysal tarafından geliştirilmiş, geçerlilik ve güvenirlik testleri yapılmış Likert türü ölçekten yararlanılmıştır. Ölçek altı faktörden (boyut) oluşmaktadır (Uysal, 2010: 76):

1- Fiziksel Baskilara Maruz Kalmak,

2- Yıldırma Sonuçlarını Yaşamak

3- İşle İlgili Kendini Gösterememe ve Olumsuz Eleştirilere Maruz Kalmak,

4- Sosyal İlişkilerde Ayırıma Uğramak

5- İtibara Saldırıyı Yaşamak

6- Tehdit İçeren ve Rahatsızlık Veren Eylemlere Maruz Kalmak

Araştırma için toplanan veriler, "Kesinlikle Katılmıyorum, Katılmıyorum, Kararsızım, Katılıyorum, Kesinlikle Katılıyorum" şeklinde hazırlanmış beşli Likert tipi ölçek ile “1,2,3,4,5” puan değerleriyle sayısallaştırılmıştır.

Araştırmada yapılan güvenilirlik analizi sonucu Cronbach's alpha değeri 0,96 olarak bulunmuştur. Kolmogorov Smirnov Z testine göre ölçek normal dağılım göstermiştir. Bu nedenle gruplar arasındaki karşılaştırmalarda parametrik testler yapılmıştır.

\section{BULGULAR}

Kırgızistan Türkiye Manas Üniversitesi'nde (KTMU) akademisyenlerin yıldırma hakkındaki tutumlarını ölçmek için yapılan bu araştırmadan elde edilen demografik bulgular aşağıda gösterilmektedir.

Tablo 1. Akademisyenlerin Demografik Özellikleri

\begin{tabular}{|c|c|c|c|c|c|c|c|}
\hline Özellikler & & Say1 & Yüzde & Özellikler & & Sayı & Yüzde \\
\hline \multirow{2}{*}{ Ülke } & Türkiye & 39 & 53,4 & \multirow{4}{*}{ Ünvan } & Prof. ve Doç. & 18 & 24,7 \\
\hline & Kırgızistan & 34 & 46,6 & & Dr. Öğr. Üy. & 16 & 21,9 \\
\hline \multirow{2}{*}{ Cinsiyet } & Erkek & 53 & 72,6 & & Arş. Gör. & 24 & 32,9 \\
\hline & Kadın & 20 & 27,4 & & Öğr. Gör. & 15 & 20,5 \\
\hline \multirow{2}{*}{ Medeni Durum } & Evli & 60 & 17,3 & \multirow{5}{*}{$\begin{array}{l}\text { Manas'taki } \\
\text { Çalışma } \\
\text { Süresi }\end{array}$} & 1 yıldan az & 10 & 13,7 \\
\hline & Bekâr & 13 & 50,4 & & $1-3$ yıl arası & 14 & 19,2 \\
\hline \multirow{3}{*}{ Yaş } & $21-30$ & 24 & 32,9 & & 3-6 y1l & 28 & 38,4 \\
\hline & $31-40$ & 24 & 32,9 & & 6-10 y1l & 18 & 24,7 \\
\hline & $41+$ & 25 & 34,2 & & 10 yıl ve üzeri & 3 & 4,1 \\
\hline \multirow{2}{*}{$\begin{array}{l}\text { Aileyle birlikte } \\
\text { yaşama }\end{array}$} & Evet & 60 & 82,2 & & & & \\
\hline & Hayır & 13 & 17,8 & & & & \\
\hline
\end{tabular}


KTMU'daki öğretim elemanlarının yıldırma eğilimlerini belirlemek için yapılan bu çalışmada, toplam 73 kişi katılmış ve bunların \%53'ü Türk, \% 47'si Kırgız kişilerden oluşmuştur. Katılımcıların büyük çoğunluğu evli ve ailesiyle beraber yaşamaktadır. Yaş dağılımları ise dengeli bir sonuç göstermiştir. Yıldırma çalışmasının cevaplanması konusunda pek çok akademisyen cevap vermek istememiş, bundan dolayı katılım düşük seviyede kalmıştır. Ayrıca anket Türkçe olarak hazırlanmış, Türkçe bilmeyen veya yeterli derecede anketi anlayamayan akademisyenler doldurmak istememişlerdir. Ünvan açısından bakıldığında en fazla araştırma görevlisi cevap vermiştir. Çalışma yılı bakımından en fazla grup 3-6 yıl arası çalışanlar oluşturmuştur.

\section{5. ÖLÇEK BULGULARI}

Yıldırma ölçeğinin geçerlilik analizi için faktör analizi yapılmış ve KMO örneklem yeterliliği 0,50 den yüksek olduğu için yeterli bulunmuştur. Ayrıca faktör analizi sonucu ifadelerin faktör yükleri de 0,50 değerinin üzerinde bulunması, ifadelerin ölçmek istenilen konuları ölçtügünü göstermektedir. Ayrıca açıklanan toplam varyans \%80,3 olarak bulunmuştur.

Tablo 2. Örneklem Yeterliliği

\begin{tabular}{lll}
\hline \multicolumn{2}{c}{ KMO and Bartlett's Test } \\
\hline Kaiser-Meyer-Olkin Measure of Sampling Adequacy. &, 626 \\
\hline \multirow{3}{*}{ Bartlett's Test of Sphericity } & Approx. Chi-Square & $5,215 \mathrm{E} 3$ \\
\cline { 2 - 3 } & $\mathrm{df}$ & 1275 \\
\cline { 2 - 3 } & Sig. &, 000 \\
\hline
\end{tabular}

\section{Yildırma Boyutları Arasındaki Korelasyonlar:}

Yıldırma ölçeğini oluşturan altı boyuta ilişkin korelasyon bulguları aşağıda gösterilmektedir.

Tablo 3. Yıldırma Ölçeğinin Boyutlarının Korelasyonları

\begin{tabular}{|c|c|c|c|c|c|c|c|c|}
\hline & & 1 & 2 & 3 & 4 & 5 & 6 & 7 \\
\hline \multirow{2}{*}{$\begin{array}{l}\text { 1. Fiziksel Baskılara Maruz } \\
\text { Kalmak }\end{array}$} & Pearson Correlation & 1 & & & & & & \\
\hline & Sig. (2-tailed) & & & & & & & \\
\hline \multirow{2}{*}{$\begin{array}{l}\text { 2. Yıldırma Sonuçlarını } \\
\text { Yaşamak }\end{array}$} & Pearson Correlation &, $502^{* *}$ & 1 & & & & & \\
\hline & Sig. (2-tailed) & 000 & & & & & & \\
\hline \multirow{2}{*}{$\begin{array}{l}\text { 3. İşle İlgili Kendini } \\
\text { Gösterememe ve Olumsuz } \\
\text { Eleştirilere Maruz Kalmak }\end{array}$} & Pearson Correlation & $349^{* *}$ & $661^{* *}$ & 1 & & & & \\
\hline & Sig. (2-tailed) & ,002 &, 000 & & & & & \\
\hline \multirow{2}{*}{$\begin{array}{l}\text { 4. Sosyal İlişkilerde Ayırıma } \\
\text { Uğramak }\end{array}$} & Pearson Correlation &, $526^{* *}$ &, $718^{* *}$ &, $701^{* *}$ & 1 & & & \\
\hline & Sig. (2-tailed) & 000 & ,000 & 000 & & & & \\
\hline \multirow{2}{*}{ 5. İtibara Saldırıyı Yaşamak } & Pearson Correlation &, $758^{* *}$ &, $779^{* *}$ & $687^{* *}$ &, $789^{* *}$ & 1 & & \\
\hline & Sig. (2-tailed) & 000 &, 000 &, 000 & 000 & & & \\
\hline \multirow{2}{*}{$\begin{array}{l}\text { 6. Tehdit İçeren ve Rahatsızlık } \\
\text { Veren Eylemlere Maruz Kalmak }\end{array}$} & Pearson Correlation & $638^{* *}$ & $640^{* *}$ & $723^{* *}$ & , $735^{* *}$ &, $717^{* *}$ & 1 & \\
\hline & Sig. (2-tailed) & 000 &, 000 &, 000 & 000 & 000 & & \\
\hline \multirow{2}{*}{ 7. Yildirma ort. } & Pearson Correlation & $674^{* *}$ & $861^{* *}$ & $845^{* *}$ & $898^{* *}$ & $912^{* *}$ & $869^{* *}$ & 1 \\
\hline & Sig. (2-tailed) & 000 &, 000 &, 000 & ,000 & ,000 & ,000 & \\
\hline
\end{tabular}

**. Korelasyon 0.01 düzeyinde anlamlıdır (Çift yönlü). 
Tablo 3'te yer alan Yıldırma ölçeğini oluşturan faktörler arasındaki korelasyonlar yüksek ve aralarındaki ilişki anlamlıdır. Bu sonuçlar yıldırma ölçeğindeki faktörlerin yıldırmayı ölçtüğünü göstermektedir.

Katılımoların Yıldırma ve Yıldırma Boyutlarına İlişkin Puanları:

Araştırmaya katılan kişilerden ede edilen yıldırma puanı ve boyutlarının puanları aşağıda gösterilmektedir.

Tablo 4. Yıldırma Boyutlarının Ortalamaları

\begin{tabular}{lccccc}
\hline & N & Min. & Max. & $\bar{x}$ & SS \\
\hline Fiziksel baskı & 73 & 1,00 & 2,25 & 1,15 &, 30921 \\
\hline Yıldırma sonuçları & 73 & 1,00 & 3,54 & 1,55 &, 66858 \\
\hline Eleştiri & 73 & 1,00 & 4,33 & 1,63 &, 70724 \\
\hline Sosyal ayrım & 73 & 1,00 & 4,29 & 1,55 &, 73585 \\
\hline İtibara saldırı & 73 & 1,00 & 3,33 & 1,38 &, 48435 \\
\hline Tehdit & 73 & 1,00 & 3,00 & 1,38 &, 54344 \\
\hline Yıldırma Ort. & 73 & 1,00 & 2,87 & 1,44 &, 49273 \\
\hline
\end{tabular}

Tablo 4'teki aritmetik ortalamalara bakıldığında en fazla eleştiri boyutunda $(\bar{x}=1,63)$ puan alındığı görülmektedir. Daha sonra sosyal ayrım $(\bar{x}=1,55)$ ve yıldırma sonuçları $(\bar{x}=1,55)$ gelmektedir. En az yıldırma puanının alındığı faktör, fiziksel baskı faktöründe görülmektedir. Cevaplayıcıların yıldırma genel ortalamasına göre $(\bar{x}=1,44)$ az yıldırma yaşadıkları tespit edilmiştir.

Katılımcıların ülkelerine göre yıldırma davranışına ilişkin ortalamaları aşağıdaki tabloda gösterilmektedir.

Tablo 5. Ülkelere Göre Yıldırma Puanları

\begin{tabular}{|l|l|c|c|c|c|}
\hline & \multicolumn{1}{|c|}{ Ülke } & $\mathrm{N}$ & $\overline{\mathrm{x}}$ & $\mathrm{SS}$ & Std. Hata Ort. \\
\hline \multirow{2}{*}{ Fiziksel bask1 } & Türkiye & 39 & 1,13 &, 28249 &, 04523 \\
\cline { 2 - 5 } & Kirgızistan & 34 & 1,16 &, 34112 &, 05850 \\
\hline \multirow{2}{*}{ Yıldırma sonuçları } & Türkiye & 39 & 1,61 &, 68210 &, 10922 \\
\cline { 2 - 6 } & Kirgızistan & 34 & 1,49 &, 65713 &, 11270 \\
\hline \multirow{2}{*}{ Eleştiri } & Türkiye & 39 & 1,60 &, 78511 &, 12572 \\
\cline { 2 - 6 } & Kirgızistan & 34 & 1,66 &, 61612 &, 10566 \\
\hline \multirow{2}{*}{ Sosyal ayrım } & Türkiye & 39 & 1,68 &, 85392 &, 13674 \\
\cline { 2 - 6 } & Kirgızistan & 34 & 1,40 &, 54612 &, 09366 \\
\hline \multirow{2}{*}{ İtibara saldırı } & Türkiye & 39 & 1,37 &, 47259 &, 07567 \\
\cline { 2 - 6 } & Kirgizistan & 34 & 1,39 &, 50455 &, 08653 \\
\hline \multirow{2}{*}{ Tehdit } & Türkiye & 39 & 1,36 &, 53140 &, 08509 \\
\cline { 2 - 6 } & Kirgizistan & 39 & 1,39 &, 56447 &, 09681 \\
\hline \multirow{2}{*}{ Yıldırma ort. } & Türkiye & 34 & 1,46 &, 54263 &, 08689 \\
\cline { 2 - 6 } & Kirgizistan &, 43536 &, 07466 \\
\hline
\end{tabular}


Katılımcıların ülkelerine göre cevaplara bakıldığında en fazla ortalamalar Eleştiri ve Sosyal ayrım boyutlarında olduğu görülmektedir. Eleştiri boyutunda Kırgızlar Türklere göre daha fazla puan almışlardır. Sosyal ayrım boyutunda ise Türk akademisyenlerin puan Kırgız akademisyenlere göre daha yüksektir.

Cinsiyet değişkeni açısından katılımcıların yıldırma puanları aşağıda gösterilmektedir.

Tablo 6. Cinsiyet Değişkenine Göre Yıldırma Ortalamaları

\begin{tabular}{|l|c|c|c|c|c|}
\hline & Cinsiyet & $\mathrm{N}$ & $\overline{\mathrm{x}}$ & $\mathrm{SS}$ & Std. Hata Ort. \\
\hline \multirow{2}{*}{ Fiziksel baskı } & Erkek & 53 & 1,14 &, 30062 &, 04129 \\
\cline { 2 - 6 } & Kadın & 20 & 1,15 &, 33907 &, 07582 \\
\hline \multirow{2}{*}{$\begin{array}{l}\text { Yıldırma } \\
\text { sonuçları }\end{array}$} & Erkek & 53 & 1,56 &, 68208 &, 09369 \\
\hline \multirow{3}{*}{ Eleştiri } & Kadın & 20 & 1,52 &, 64758 &, 14480 \\
\hline \multirow{3}{*}{ Sosyal ayrım } & Erkek & 53 & 1,53 &, 60415 &, 08299 \\
\cline { 2 - 6 } & Kadın & 20 & 1,87 &, 89976 &, 20119 \\
\hline \multirow{2}{*}{$\begin{array}{l}\text { Itibara } \\
\text { saldırı }\end{array}$} & Erkek & 53 & 1,59 &, 74005 &, 10165 \\
\hline \multirow{2}{*}{ Tehdit } & Kadın & 20 & 1,45 &, 73372 &, 16406 \\
\cline { 2 - 6 } & Kadıek & 53 & 1,36 &, 42374 &, 05821 \\
\hline \multirow{2}{*}{ Yıldırma ort. } & Erkek & 53 & 1,44 &, 62647 &, 14008 \\
\cline { 2 - 6 } & Kadın & 20 & 1,34 &, 47114 &, 06472 \\
\cline { 2 - 6 } & Erkek & 53 & 1,46 &, 70838 &, 15840 \\
\hline \multirow{2}{*}{ Kadın } & 20 & 1,48 &, 47027 &, 06460 \\
\hline
\end{tabular}

Araştırmaya katılan kişilerin yıldırma ortalamalarına bakıldığında bayanların puanları $(\bar{x}=1,48)$ erkeklere göre $(\bar{x}=1,42)$ biraz daha yüksek bulunmuştur. Boyutlar açısından bakıldığında ise fiziksel baskı, eleştiri, itibara saldırı ve tehdit boyutlarında bayanların ortalaması daha yüksektir. Yıldırma sonuçları ve sosyal ayrım boyutlarında erkeklerin puanları bayanlarınkinden daha yüksek olarak tespit edilmiştir.

Demografik Özellikler Açısından Yıldırma Karşılaştırmaları:

Araştırmaya katılan akademisyenlerin demografik özelliklerine göre yıldırma ve yıldırma faktörleri bakımından farklılıkların olup olmadığı araştırılmıştır. İkili gruplarda t testi, üç ve daha fazla gruplarda ise Anova analizi kullanılmıştır.

Aşağıda akademisyenlerin ülkeleri açısından elde edilen Yıldırma boyutlarındaki farklılıklardan elde edilen bulgular gösterilmektedir.

Tablo 7. Akademisyenlerin Ülkeleri Açısından Yıldırma Farklılığı

\begin{tabular}{|l|c|c|c|c|c|c|}
\hline & Ülke & $\mathrm{N}$ & $\overline{\mathrm{x}}$ & $\mathrm{SS}$ & $\mathrm{t}$ & $p$ \\
\hline \multirow{2}{*}{$\begin{array}{l}\text { Sosyal } \\
\text { Ayrım }\end{array}$} & Türkiye & 39 & 1,68 &, 8539 & \multirow{2}{*}{1,647} & \multirow{2}{*}{, 022} \\
\cline { 2 - 5 } & Kirgizistan & 34 & 1,40 &, 5461 & & \\
\hline
\end{tabular}


Tablo 7'deki akademisyenlerin ülkeleri açısından yıldırma boyutları arasında, sadece Sosyal Ayrim boyutunda $(t=1,647, \quad p=0,022<0,05)$ farklılık bulunmuştur. Türkiye'den gelen akademisyenler, daha fazla sosyal ayrıma uğradıklarını düşünmektedirler.

Tablo 8. Cinsiyet Açısından Yıldırma Farklılıkları

\begin{tabular}{|l|l|c|c|c|c|c|}
\hline & Cinsiyet & $\mathrm{N}$ & $\overline{\mathrm{x}}$ & $\mathrm{SS}$ & $\mathrm{t}$ & $p$ \\
\hline \multirow{3}{*}{ Eleştiri } & Erkek & 53 & 1,53 &, 60415 & \multirow{2}{*}{1,847} & \multirow{2}{*}{, 013} \\
\cline { 2 - 6 } & Kadın & 20 & 1,87 &, 89976 & & \multirow{2}{*}{, 026} \\
\hline \multirow{2}{*}{ Tehdit } & Erkek & 53 & 1,34 &, 47114 & \multirow{2}{*}{, 793} & \\
\cline { 2 - 5 } & Kadın & 20 & 1,46 &, 70838 & & \\
\hline
\end{tabular}

Cinsiyet açısından farklılıklara bakıldığında; eleştiri $(t=1,847, p=0,013<0,05)$ ve tehdit $(t=, 793$, $\mathrm{p}=0,026<0,05)$ boyutlarında kadınlar ile erkekler farklı düşünmektedirler. Kadınlar bu boyutlardan daha fazla puan alarak eleştiriye ve tehdide daha fazla maruz kaldıklarını belirtmişlerdir.

Tablo 9. Ünvan Açısından Yıldırma Farklılıkları

\begin{tabular}{|c|c|c|c|c|c|c|}
\hline & & $\mathrm{N}$ & $\bar{x}$ & SS & $\mathrm{F}$ & $p$ \\
\hline \multirow{5}{*}{$\begin{array}{l}\text { Yıldırma } \\
\text { Sonuçları }\end{array}$} & Prof. ve Doç. & 18 & 1,28 & ,47110 & \multirow{5}{*}{2,889} & \multirow{5}{*}{,042 } \\
\hline & Dr. Öğr. Üyesi & 16 & 1,40 &, 52527 & & \\
\hline & Arş. Gör. & 24 & 1,64 & 75499 & & \\
\hline & Öğr. Gör. & 15 & 1,89 & ,73533 & & \\
\hline & Toplam & 73 & 1,55 & 66858 & & \\
\hline \multirow{5}{*}{ Eleştiri } & Prof. ve Doç. & 18 & 1,30 & 39709 & \multirow{5}{*}{5,094} & \multirow{5}{*}{,003 } \\
\hline & Dr. Öğr. Üyesi & 16 & 1,48 & ,46535 & & \\
\hline & Arş. Gör. & 24 & 1,63 &, 56247 & & \\
\hline & Öğr. Gör. & 15 & 2,16 & 1,07828 & & \\
\hline & Toplam & 73 & 1,63 & 70724 & & \\
\hline \multirow{5}{*}{$\begin{array}{l}\text { Yıldırma } \\
\text { ort }\end{array}$} & Prof. ve Doç. & 18 & 1,21 & ,28623 & \multirow{5}{*}{3,100} & \multirow{5}{*}{,032 } \\
\hline & Dr. Öğr. Üyesi & 16 & 1,38 & 45327 & & \\
\hline & Arş. Gör. & 24 & 1,48 & ,52324 & & \\
\hline & Öğr. Gör. & 15 & 1,70 &, 57527 & & \\
\hline & Toplam & 73 & 1,44 & 49273 & & \\
\hline
\end{tabular}

Ünvanlar açısından yıldırma faktörlerine bakıldığında; yıldırma sonuçları (F=2,889, $p=0,042<0,05)$, eleştiri $(F=5,094, p=0,003<0,05)$ ve yıldırma ortalaması $(F=3,100, p=0,032<0,05)$ bakımından farklılıklar tespit edilmiştir. Bu bulgulara göre öğretim görevlileri ile araştırma görevlileri en fazla ortalamaya sahip iki gruptur. En az puan ise profesör ve doçent grubundadir. 
Akademisyenlerin çalışma yıllarına ilişkin tespit edilen farklılıklar tabloda gösterilmektedir.

Tablo 10. Çalışma Yıllarına Göre Yıldırma Farklılıkları

\begin{tabular}{|c|c|c|c|c|c|c|}
\hline & & $\mathbf{N}$ & $\overline{\mathrm{x}}$ & SS & $\mathbf{F}$ & $p$ \\
\hline \multirow{6}{*}{ Eleştiri } & 1 yıldan az & 10 & 1,28 & ,36893 & \multirow{6}{*}{3,014} & \multirow{6}{*}{,024 } \\
\hline & 1-3 yıl arası & 14 & 1,44 & ,37329 & & \\
\hline & $3-6$ yil & 28 & 1,79 & ,76662 & & \\
\hline & 6-10 y1l & 18 & 1,55 & 63658 & & \\
\hline & 10 yıl ve üzeri & 3 & 2,61 & 1,34860 & & \\
\hline & Toplam & 73 & 1,63 & ,70724 & & \\
\hline \multirow{6}{*}{ Tehdit } & 1 yıldan az & 10 & 1,12 & 31732 & \multirow{6}{*}{2,312} & \multirow{6}{*}{,046 } \\
\hline & 1-3 yil arası & 14 & 1,21 & ,32310 & & \\
\hline & $3-6$ yil & 28 & 1,58 & ,68736 & & \\
\hline & 6-10 yil & 18 & 1,29 & ,39528 & & \\
\hline & 10 yıl ve üzeri & 3 & 1,66 & ,72169 & & \\
\hline & Toplam & 73 & 1,38 &, 54344 & & \\
\hline
\end{tabular}

Tablo 10' da gösterilen çalışma yıllarına göre yapılan Anova bulgularına göre, eleştiri ( $\mathrm{F}=3,014$, $\mathrm{p}=0,024<0,05)$ ve tehdit $(\mathrm{F}=2,312, \mathrm{p}=0,046<0,05)$ boyutlarında farklılıklar bulunmuştur. Manas Üniversitesinde çalışan akademik personel arasında 3-6 yıl çalışan grup ile 6-10 yıl çalışanlar daha fazla eleştiriye ve tehdide maruz kaldıklarını düşünmektedirler.

\section{SONUÇ VE ÖNERILER}

Yıldırma konusu Türkiye'de 2000'li yıllardan sonra çalışılmaya başlanmış olan bir konudur. Bu konuya hükümet de el atmış ve gerekli yasal düzenlemeleri yapmıştır. Kardeş ülke olan Kırgızistan'da ise bu konu oldukça yenidir ve bu konuda yapılan çalışmalar oldukça azdır. Bu çalışmayla Kırgızistan Türkiye Manas Üniversitesinde (KTMU) akademik personelin yıldırma (mobbing) hakkındaki algılamaları belirlenmeye çalışılmıştır. Araştırmaya dahil olan akademisyen sayısının nispeten az olması, çalışmanın genelleştirilmesinin kısıtlarından biridir.

Araştırmanın temel sonuçları olarak; Türkiye'den gelen akademisyenler daha fazla sosyal ayrıma tabi tutulduklarını düşünmekte, bayan akademisyenler daha fazla eleştiriye ve tehdide maruz kaldıklarını belirtmekteler, araştırma görevlileri ve öğretim görevlileri daha fazla yıldırmaya tabi olduklarını düşünmektedirler. Ayrıca KTMU'da 3-6 yıldan beri çalışan akademisyenler eleştiri ve tehdit açısından daha yüksek puan almışlardır. Yıldırma ölçeğinin genel ortalaması açısından değerlendirme yapıldığında ise Türkiye'den gelen akademisyenlerin puanları Kırgız akademisyenlere göre daha yüksek olarak bulunmuştur.

Bu sonuçlara göre tavsiye olarak şunlar belirtilebilir:

- Türkiye'den gelen akademisyenler, özellikle ailesiyle ve çocuklariyla beraber gelenler, gerçekten çok önemli ve radikal bir karar vererek Kırgızistan'a gelmektedirler. Çünkü alıştıkları bir düzeni bozarak ve bir bakıma çocuklarının geleceğini de etkileyecek bir karar vererek ve de hayat standartlarındaki kaliteden ve güvenden vazgeçerek Kırgızistan'a gelmektedirler. Bu nedenle yöneticilerin, özellikle Türkiye'den gelen tüm akademisyenlere, yeni ve eşyaları tam olan ve de fiziksel ihtiyaçların tam olarak karşılandığı bir sistemi hayata geçirmeleri gerekir. 
- Yeni gelen Türk akademisyenlere ve de ailelerine daha fazla intibak programları ve destek programları devreye sokulmalıdır.

- Genel olarak yıldırma puanlarının düşük çıkmasına rağmen yapılan $t$ testinde bayanlar daha fazla yıldırıldıklarını düşündüklerinden bu konuda daha detaylı bir çalışma yapılabilir. Değişik toplantılarda bu konu gündeme getirilip gerekli seminerler tertip edilebilir.

- Araştırma görevlileri ve öğretim görevlileri ile daha kapsamlı çalışma yapılıp onların sıkıntıları tespit edilip çareler aranmalıdır.

- Çalışma yılları açısından üç yıldan fazla bu üniversitede çalışan akademik personelin daha fazla sıkıntı içerisinde olduğu görülmektedir. Bu durum, belki üç yıldan fazla lojmanda kalamamasından kaynaklanmış olabilir. Manas Üniversitesinin Lojman Yönetmeliğine göre, idari görevi olmayan akademik personel üç yılın sonunda lojmandan çıkmak zorundadır. Bu durumda dışarıda bir daire kiralamak zorunda kalan akademisyen oldukça yüksek kira vererek, daha küçük ve bakımsız binalarda kalmak durumundadır. Kampüsteki eski lojmanda birtakım sıkıntılar bulunmaktadır. Bu nedenle idarenin yeni bir lojman daha yaparak akademik personelin dışarıda kalmasına mani olmasında fayda bulunmaktadır.

- Akademisyenlerin ders, görev ve komisyon dağılımlarında daha dengeli görevlendirmeler yapılabilir ve verilen görevlerde gerekli destekler sağlanmalıdır.

- Ayrıca akademik faaliyetlerin gerçekleştirilmesinde maddi ve manevi ödüller daha kapsamlı ve sistemli olarak gerçekleştirilebilir.

Kırgızistan Türkiye Manas üniversitesinde gerçekleştirilen bu araştırma, sadece Türkçe olarak hazırlanan anket ile yapılmıştır. Daha kapsamlı yapılacak olan çalışmalarda Kırgızca ve Rusça versiyonlarının da hazırlanmasında fayda vardır. Ayrıca genel olarak akademik camiada yıldırma puanları genelde düşük çıkmaktadır. Bunun için başka çalışmalarda idari personelle ilgili çalışmalar yapılabilir.

\section{KAYNAKÇA}

Altınkurt, Y. K. (2012). Üniversite Çalışanlarının Psikolojik Yıldırma Algıları İle Denetim Odağ 1 Arasındaki İlişki. Balıkesir Üniversitesi Sosyal Bilimler Enstitüsü, Eğitim Bilimleri Anabilim Dalı, Yayımlanmamış Yüksek Lisans Tezi, Balıkesir.

Coşkuner, S., Coştur, R., Bayhan Karapınar, P., Metin Camgöz, S., Ceylan, S., Demirtaş Zorbaz, S., Feyza Aktaş, E., \& Çiffiliz, G. (2018). Mobbing, Organizational Identification, and Perceived Support: Evidence from a Higher Education Institution. Eurasian Journal of Educational Research, 73, 19-40.

Fettahlığlu, Ö. O. (2008). Örgütlerde Psikolojik Şiddet (Mobbing): Üniversitelerde Bir Uygulama. Dokuz Eylül Üniversitesi, SBE Yayımlanmamış Doktora Tezi, İzmir.

Güven, A., Kaplan, Ç., \& Acungil, Y. (2018). Türkiye'de Özel ve Kamu Üniversitelerinde Çalışan Akademisyenlerin Mobbing Algısı. Akademik Araştırmalar ve Çalışmalar Dergisi, 10 (18): 43-58. 
Hacıcaferoğlu S. (2010). Gençlik ve Spor İl Müdürlüğü Personelinin Çalışma Ortamlarında Maruz Kaldıkları Yıldırma Davranışları. Fırat Üniversitesi, Sağlık Bilimleri Enstitüsü, Yüksek Lisans Tezi, Elazı̆̆.

Irak, D. U. (2019). Personality and Experience of Mobbing: Three Types of Mobbing and the Consequences at the Workplace. İş ve İnsan Dergisi, Nisan, 6 (1), 55-66.

Keashly, L., \& Neuman, J. H. (2013). Bullying in Higher Education: What Current Research, Theorizing, and Practice Tell Us. Ed. J. Lester, Workplace Bullying in Higher Education (pp. 1-22).

Kocaoğlu, M. (2007). Mobbing Uygulamaları ve Motivasyon Arasındaki İlişkinin İncelenmesine Yönelik Bir Araştırma. Yıldız Teknik Üniversitesi, Sosyal Bilimler Enstitüsü, Yüksek Lisans Tezi, İstanbul.

Kök, S. (2006). İş Yaşamında Psiko-Şiddet Sarmalı Olarak Yıldırma. 14. Yönetim Organizasyon Kongresi Bildiriler Kitabı, Atatürk Üniversitesi, Erzurum, 161-170.

Köse, S., \& Uysal, Ş. (2010). Kamu Personelinin Yıldırma ve Boyutları Hakkındaki Düşünceleri Üzerinde Bir Çalışma: Manisa İl Tarım Müdürlüğü Örneği, Celal Bayar Üniversitesi SBE, Sosyal Bilimler Dergisi, 8(1), 261-276.

Leymann, H. (1990). Mobbing and Psychological Terror at Workplaces. Violence and Victims, 5(2), 119-126.

Mete, Y. A, (2013). Yüksek Öğretim Kurumlarında Psikolojik Yıldırma (Terör) : Uygulayanlar, Mağdurlar ve Seyirciler, International Journal of Social Science, 6(2), 977-993.

Minibaş P. J. (2018). Mobbing in Higher Education: Descriptive and Inductive Case Narrative Analyses of Mobber Behavior, Mobbee Responses, and Witness Support. Kuram ve Uygulamada Ĕ̈itim Bilimleri, 18(2), 471- 494.

Öztürk, A. (2019). Akademisyenlerin Algıladıkları Mobbing ve Mesleki Tükenmişlik Düzeylerinin Çeşitli Değişkenlere Göre İncelenmesi. IBAD Sosyal Bilimler Dergisi, Sayı: Özel Sayı, 314-325.

Pugh, L. B., \& Krestelica, D. (2019). Bullying in Higher Education: Culture Change Requires More Than Policy. Perspectives: Policy and Practice in Higher Education, 23(2-3), 109-114.

Şahin, M. (2013). Mobbing Olgusuna Anatomik Bir Bakış: Üniversite Özelinde Vaka Analizi. Akademik Bakış Dergisi, Sayı: 38, Eylül - Ekim, 1-20.

Uysal, Ş. (2010). Çalışma Yaşamında Yıldırma (Mobbing) ve Boyutları; Manisa Kamu Kurumları Üzerinde Bir Araştırma. Celal Bayar Üniversitesi, Sosyal Bilimler Enstitüsü, Yüksek Lisans Tezi, Manisa.

Yorulmaz, M. (2019). Türkiye'de Mobbing Konusunda Yapılan Tez Çalışmaları: Meta Analizi. Uluslararası Sosyal Araştırmalar Dergisi, 12(62), 1636-1644.

İstatistiklerle Manas, (2018). http://bis.manas.edu.kg/manasbis/istatistiklerlemanas2018.pdf, (Erişim: 30.10.2019) 